遺伝性出血性毛細血管拡張症の鼻出血治療経験

ーアルゴンプラズマの有用性に関する検討一

鈴木 治子1) ・ 今村 俊一12) ・ 本田 英幸2) ・ 宇佐美真一1)

\title{
Argon Plasma Treatment for the Nasal Bleeding Caused by Hereditary Hemorrhagic Telangiectasia
}

\author{
Haruko Suzuki and Shin-ichi Usami \\ (Shinshu University) \\ Shun-ichi Imamura \\ (Shinshu University, Suwa Central Hospital) \\ Hideyuki Honda \\ (Suwa Central Hospital)
}

\begin{abstract}
A 50-year-old man presented with recurrent epistaxis and iron-deficiency anemia. His mother and niece also experienced recurrent epistaxis, and his grandmother, an uncle and two aunts died from severe epistaxis. He had multiple telangiectasia in the nasal mucosa, soft and hard palate, lip, tongue and conjunctiva. He also had experienced hematomesis, and telangiectasia of the stomach was found by gastroendoscopy. He was diagnosed as hereditary hemorrhagic telangiectasia (HHT), because of his family history, recurrent epistaxis, and multiple telangiectasias. We tried various treatments, such as steroid collunarium to the nose, oral tranexamic acid and anti-inflammatory drugs for epistaxis, but it could not be controlled effectively, and severe daily epistaxis required blood transfusion. Thus, next we used argon plasma for irradiating telangiectasia of nasal cavity under endoscopic observation and obtained good control of the epistaxis. In this report, we present the clinical history and treatment results in this case, review the literature and summarize various treatments for recurrent epistaxis in HHT.
\end{abstract}

Key words : argon plasma, HHT, epistaxis

はじめに

Hereditary hemorrhagic telangiectasia (Osler-WeberRendu syndrome; 以下HHT と省略する) は1896年にRendu が初めて報告した常染色体優性遺伝性疾患である。近年 endoglin や activin receptor-like kinase 1 (ALK-1) gene 変異 の関与が報告されている(1)2). HHT は全身の皮膚, 粘膜, 腸管等の多発性毛細血管拡張と肺，脳などに動静脈奇形
を有し，それらの破裂や出血を伴う全身疾患である。な かでも鼻出血は初期からみられ，HHT 患者の $90 \%$ 以上 に合併する頻度の高い症状である ${ }^{3)}$ ）．その鼻出血は反 復性でかつ治療抵抗性であり，われわれ耳鼻咽喉科医が これに遭遇することもまれではなく，その診断および治 療に難渋することがしばしばある。これまで症状の程度 によりトラネキサム酸9) やアミノカプロン酸10) などの薬

1）信州大学耳鼻咽喉科学教室

2）諏訪中央病院耳鼻咽喉科 
剂投与, ホルモン療法 8111 ), 電気凝固, 各種レーザー治 療4)5779912)，塞栓術12133，放射線外照射14)，鼻中隔皮膚形 成術15), 前頭皮弁等による鼻粘膜置換術16)17) などさまざ まな治療法が試みられてきた。しかし，いまだ本疾患に おける重篤な鼻出血に対する確実な治療法はなく, 簡便 で安全かつ有効な治療法の確立が望まれている。今回わ れわれは, 反復性鼻出血に対しアルゴンプラズマ凝固 法 (argon plasma coagulation：以下 APC と省略する) を用 い，これが出血の抑止に有効であった HHT 症例を経験 したのでこれを報告する，さらに HHT の難治性鼻出血 に対する治療法の選択につき若干の文献的考察を加え報 告する.

\section{症例}

症例：50 歳, 男性.

主訴：反復性鼻出血.

既往歴：出血性胃炎（1999 年 7 月 25 日）.

家族歴：母方の祖母, 母方の叔父 1 人と叔母 2 人が鼻 出血で死亡し, 母親, 姪に難治性鼻出血を認めている.

現病歴：1999 年秋頃より鼻出血をほぼ毎日反復するよ うになった。 1 回の出血は数分程度, 圧迫により比較的 容易に止血可能で比較的短時間であるが日に数回認め た. 1999 年 10 月 7 日, 精查加療目的に諏訪中央病院耳 鼻咽喉科を初診となる。初診時右方への鼻中隔弯曲, 右 鼻中隔粘膜より静脈性の出血を認めた。出血は 5000 倍エ ピネフリン, $4 \%$ キシロカイン等量混合液の塗布により容 易に止血した。

血液検查所見：1999 年 10 月 7 日 (初診時), WBC： $4800 / \mu \mathrm{l}, \mathrm{RBC}: 365 \times 10^{4} / \mu \mathrm{l}, \mathrm{Hb}: 11.9 \mathrm{~g} / \mathrm{dl}, \mathrm{Ht}: 36 \%$, PLT : $24.3 \times 10^{4} / \mu 1$, GOT $: 29 \mathrm{IU} / 1$, GPT $: 14 \mathrm{IU} / 1, \mathrm{LDH}:$ $203 \mathrm{IU} / 1, \mathrm{CPK}: 58 \mathrm{IU} / 1, \mathrm{ALP}: 120 \mathrm{IU} / 1, \gamma \mathrm{GTP}: 91 \mathrm{IU} / 1$, ALP : $120 \mathrm{IU} / \mathrm{l}, \mathrm{LAP}: 55 \mathrm{IU} / \mathrm{l}, \mathrm{T}-\mathrm{Bil}: 0.32 \mathrm{mg} / \mathrm{dl}, \mathrm{D}-\mathrm{Bil}: 0.15 \mathrm{mg} /$ dl, BUN $: 4.5 \mathrm{mg} / \mathrm{dl}, \mathrm{Fe}: 27 \mu \mathrm{g} / \mathrm{dl}, \mathrm{Na}: 140 \mathrm{mEq} / 1, \mathrm{~K}$ : $4.3 \mathrm{mEq} / 1, \mathrm{Cl}: 110 \mathrm{mEq} / \mathrm{l}, \mathrm{PT}: 10.0$ 秒, APTT : 26.0 秒, 出血時間 : 2 分 30 秒, 凝固時間 : 7 分 30 秒。

2002 年 10 月 25 日 (頻回出血後で輸血前), $\mathrm{RBC}: 150$ $\times 10^{4} / \mu \mathrm{l}, \mathrm{Hb}: 4.9 \mathrm{~g} / \mathrm{dl}, \mathrm{Ht}: 16.7 \%$, PLT : $31.1 \times 10^{4} / \mu \mathrm{l}$, MCV : $111.3 \mathrm{fl}, \mathrm{MCH}: 32.7 \mathrm{pg}, \mathrm{MCHC}: 29.3 \%$.

口腔所見：軟・硬口蓋（図 1), 舌および下口唇（図 2) に毛細血管拡張を認めた。

眼所見：眼瞼結膜に毛細血管拡張を認めた。

鼻内所見 : 右方一の鼻中隔弯曲, 両側鼻中隔粘膜や下

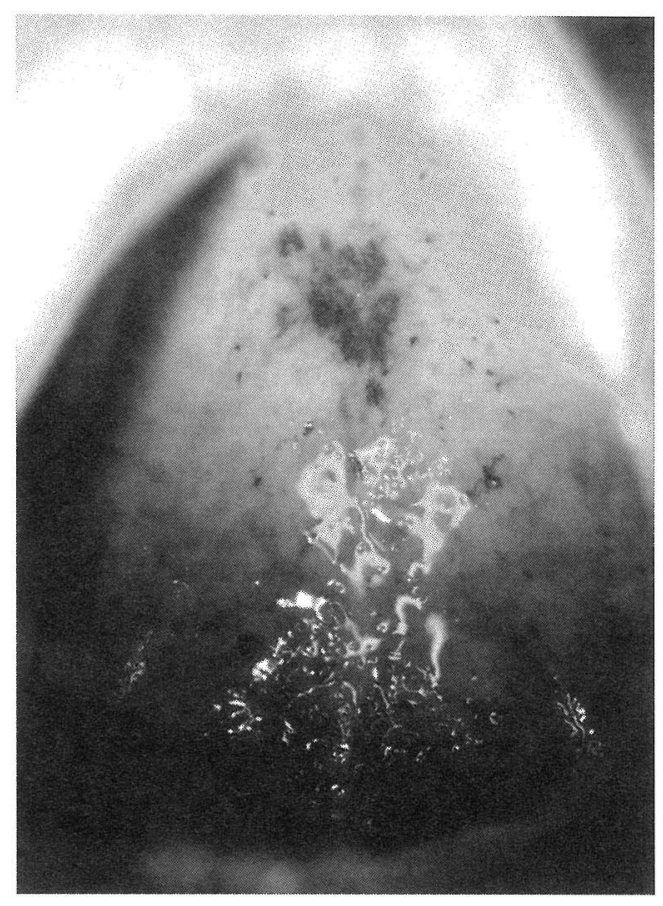

図 1 軟・硬口蓋所見

軟口蓋, 硬口蓋粘膜に広範囲に毛細血管拡張を認めるが 出血は認めない。

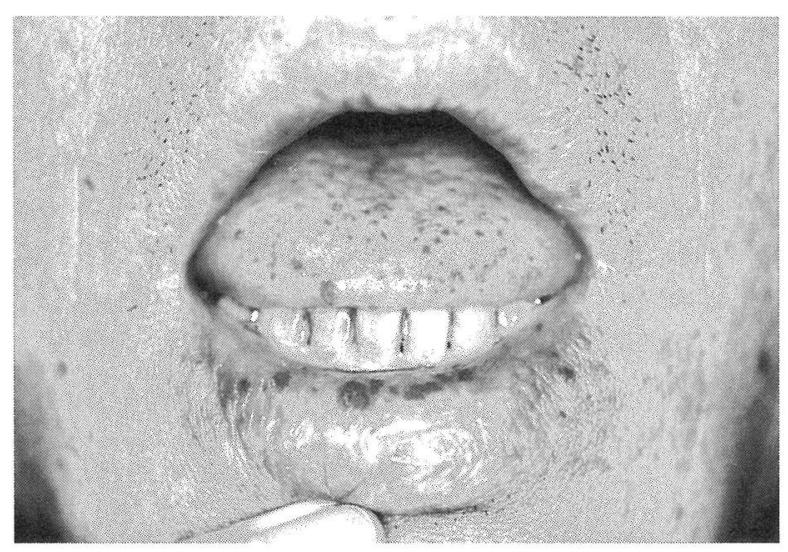

図 2 舌, 下口唇所見

舌表面㧍よび下口唇に点状の毛細血管拡張を多数認め る.

鼻甲介粘膜を中心に多発性の毛細血管拡張（図 3) を認 め, 鼻中隔右側の櫛部から静脈性の出血を認めた。

上部消化管内視鏡検查 : 出血性胃炎, 胃粘膜の毛細血 管拡張が散在した（図 4）。食道には異常所見は認めな かった。 


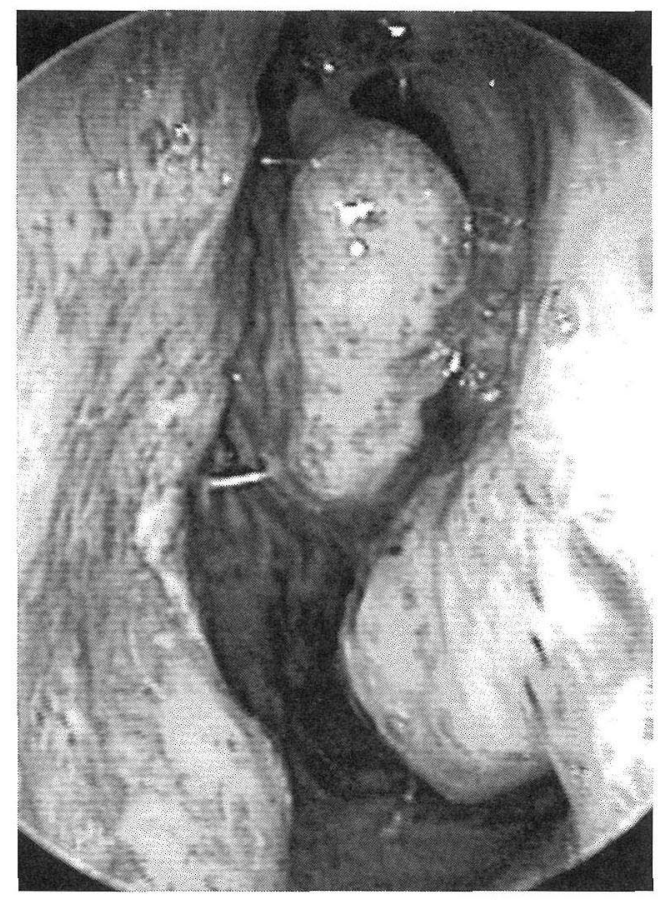

図 3 鼻腔内視鏡所見

鼻中隔粘膜に多発性の毛細血管拡張を認める. 特に弯曲の尖端（櫛部）やキーゼルバッハ部位に著明で ある。

胸腹部 CT：明らかな異常なし。

副鼻腔 CT : 副鼻腔内に明らかな異常陰影なし。粘膜 肥厚も認めなかった。

頭部 MRI：動静脈奇形，動脈瘤なし。

治療：ステロイド点鼻，止血剂（トランサミン ${ }^{\circledR}$ ) 内 服，局所処置，消炎剂内服を継続していたが出血の抑止 が不十分で，連続する中等量の鼻出血による失血性の貧 血に対し輸血が必要となった。このため 2002 年 12 月 11 日，信州大学耳鼻咽喉科外来にて，APC300（(株）アム コ製）による下鼻甲介と鼻中隔の焼灼を局所麻酔下に施 行した。エピネフリンーキシロカイン混合液にて十分に 鼻腔内を表面麻酔し鼻粘膜を損傷しないよう注意しなが ら痂皮を除去し，血管拡張部を内視鏡にて観察しながら 明視下におき，可及的にアルゴンプラズマ凝固法にて焼 灼した。焼灼後は抗生剂軟膏を塗布したスポンジェルを 留置し, 術後出血予防と粘膜の保護とした。

経過：痂皮形成は当科で施行している $\mathrm{CO}_{2}$ レーザー燒 灼後と比較すると軽微であった．留置したスポンジェル は2 日後には，自然抜去されたが出血はなかった。十分

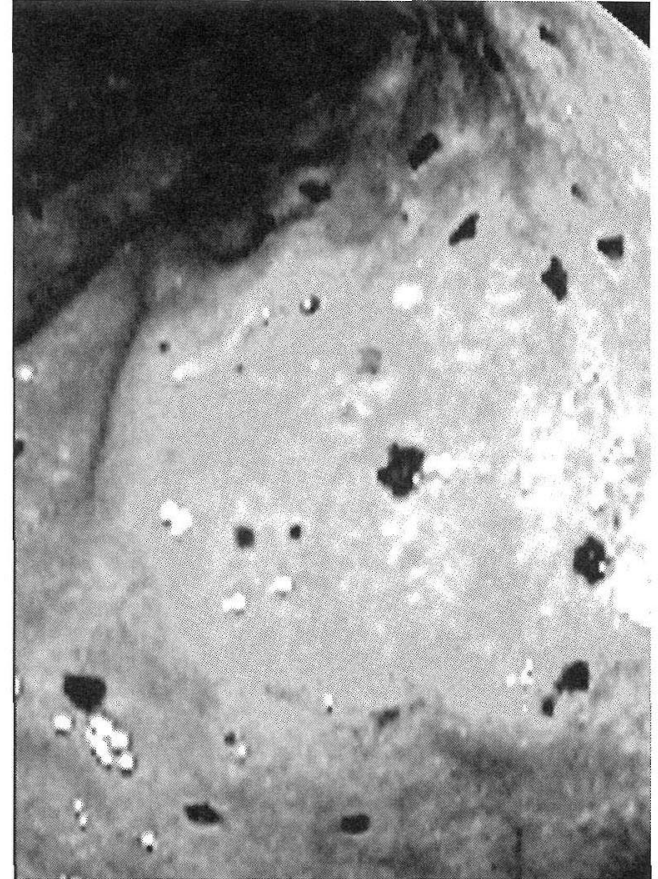

図 4 胃内視鏡所見

胃粘膜に毛細血管拡張が点状に散在している。

に焼灼できた左鼻腔からの出血はほとんどなく，鼻中隔 弯曲のため焼灼が不十分であった右鼻腔より週に 1 回程 度の軽微な出血がみられる程度で焼灼 6 力月後の現在ま で良好な状態にコントロールされている。

\section{考察}

診断 : Scientific Advisory Board of the HHT Foundation International, Inc. によると, 鼻出血, 毛細血管拡張, 内臓 病変，遺伝性を疑わせる家族歴を 4 主徴として，このう ち 3 項目が揃うと HHT と診断するとされている。この らち 2 項目では確定診断とはならず臨床的に HHT の可 能性を示唆するに留まる18）（表 1)。自験例では反復性鼻 出血，3 代にわたる家族歴，鼻粘膜や胃粘膜の多発性血 管拡張病変の 3 項目が認められ，内臓病変は確認されて いないが HHT と診断した。本症例で受診の契機となっ た鼻出血はHHT 患者の約 $90 \%$ に合併するといわれてい る314)7)。また $50 \%$ の患者が 10 歳までに，80 〜 90\%が 30 歳代までに反復性鼻出血を発症するとの報告もある319). またその程度は週に $2 \sim 3$ 回程度の軽症の鼻出血汃ら輸 血をたびたび必要とし，生命を脅かすような重症例まで さまざまである，妊娠中に鼻出血の改善を認める15)，ま 
表 1 HHT（遺伝性毛細血管拡張症）診断基準

\begin{tabular}{|c|c|}
\hline 項目 & 件 \\
\hline 1 鼻出血 & 自発性で反復性であること. \\
\hline 2 毛細血管拡張 & $\begin{array}{l}\text { 特徵的な部位 (口唇, 口空粘膜, 指, 鼻腔 } \\
\text { 粘膜) に多性にられこ。 }\end{array}$ \\
\hline 3 内臓病変 & 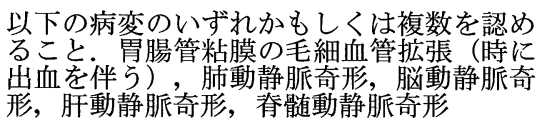 \\
\hline 4 家族歴 & 一等親内の HHT 患者の存在すること. \\
\hline \multicolumn{2}{|c|}{ 確定診断：上記の 3 項目が存在するもの } \\
\hline \multicolumn{2}{|c|}{ 疑 い 例：上記の 2 項目が存在するもの } \\
\hline \multicolumn{2}{|c|}{ 除 外 例：上記の 1 項目だけが存在し, そのほかが否定され } \\
\hline
\end{tabular}

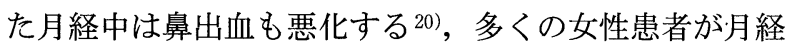
過多を経験している12)など出血と女性ホルモンとの関連 む報告されており, HHT 患者家族内の未発症女性に関し ての検索も重要といえる.

次に毛細血管拡張の部位としては口唇, 口腔粘膜, 指, 鼻腔粘膜があり，内臟病変としては胃腸粘膜の毛細血管 拡張のほか, 肺, 肝臓, 脳などに動静脈奇形が合併する ことがあるが，本症例では CT，MRI によりこれらの動 静脈奇形は否定されている。 また，まれではあるが脊髄 動静脈奇形 ${ }^{18)}$ ，動脈瘤6) の合併も起こりらる。このうち 特に肺動静脈奇形は HHT 患者の $5 \sim 15 \%$ に合併し，逆 に肺動静脈奇形患者の約 $60 \%$ がその基礎疾患として HHT を持つとされている ${ }^{21)}$.

治療：通常，鼻出血ではエピネフリン等の血管収縮剤 をしみ込ませたタンポンの挿入にて止血を試みるが, HHT では静脈壁の平滑筋や弾性線維層が欠如している ためタンポン挿入による粘膜の微小な傷害によりさらな る鼻出血を引き起こす可能性が考慮される，また安易な 鼻粘膜の焼灼は血管拡張部を保護しているはずの正常鼻 粘膜を傷害することとなり，新たな鼻出血の原因となる 恐れがある，止血の際には鼻粘膜の保護を念頭に置き， エピネフリンをしみ込ませたスポンジェルの挿入やバ ルーンの挿入は有効とされている．さらに動脈結紮や塞 栓術を併用することによりある程度の効果は期待できる が，これらの効果は持続しないことが多いようである. 欧米では古くからさまざまな治療法が報告されている が, 本邦においてその治療報告はほとんどみられない。 上記以外に Vase ら ${ }^{11}$ は, エストロゲン療法で粘膜の扁平 上皮化生により粘膜を肥厚させることで鼻出血が軽減す
る可能性を報告している．また各種レーザー治療を用い た治療法が試行され，それぞれのレーザーの特色により さまざまな治療効果が報告されている45)778)12216)17722223). $\mathrm{Nd}$ : YAG レーザー4)7715)16), アルゴンレーザー5)12), KTP レーザー ${ }^{15222)}, \mathrm{CO}_{2}$ レーザー15)23)，これらに加え今回使 用した APC が挙げられる. Nd:YAG レーザーは $1064 \mathrm{~nm}$ の波長を持ち, 色の付いた部位（血管内のへモグロビン） に吸収されにくく，他のレーザーと比較して，より深い 組織の凝固が可能である. また KTP レーザー, アルゴン レーザーは，それぞれ $532 \mathrm{~nm}, 188 \sim 514 \mathrm{~nm}$ とほぼ同 等の波長を持つ可視光で有色組織（へモグロビン）に吸 収される特徴がある ${ }^{4) 7} . \mathrm{CO}_{2}$ レーザーは粘膜自体にも吸 収されるため粘膜傷害を引き起こし HHT ではあまり有 効とはいえない. APC は, Bergler ら ${ }^{824)}$ が HHT の治療 に応用し，その実際の出血抑制効果を報告している. 本 邦ではアレルギー性鼻炎の治療に使用した経験が報告さ れている ${ }^{25226)}$. 今回われわれが使用した APC300 はアル ゴンガス（アルゴンプラズマ）と電気手術のモノポーラ エネルギー（高周波電流）を合体させた装置である. ア ルゴンプラズマビームを介して, 組織表面に到達した高 周波電流は，組織内で発熱を起こし乾燥（desiccation）, 凝固 (coagulation) および失活 (devitalization) のような熱 効果を起こす 24)277. アルゴンレーザーは蒸散作用を持ち, その深達度が深い。これに比較し, APC は乾燥で組織が 電気伝導性を失うとプラズマビームは方向転換するた め, 組織を浅く均一に凝固させることが可能となってい る ${ }^{2427)}$. 自験例でも血管を中心に浅く焼灼することがで き, 比較的周辺組織の損傷も少なかった。 また短時間で の焼灼が可能で, 処置中, 処置後の出血もほとんぞ認め なかった。多少の疼痛はあるが表面麻酔下での施行は十 分可能であった。 術後 6 力月とまだ観察期間は短期間で はあるが出血の頻度は明らかに減少し, 患者本人の満足 も得られている.

治療の適応：近年，これらの各種の治療法を鼻出血の 重症度に合わせ選択する試みが散見される7)122. 鼻出血

表 2 鼻出血の重症度分類

\begin{tabular}{lcc}
\hline \hline \multicolumn{1}{c}{ 重症度 } & \multicolumn{1}{c}{ 頻 度 } & 輸血回数 \\
\hline 軽 症 (mild) & 週に $2 \sim 3$ 回の出血 & なし \\
中等症 (moderate) & 日に $1 \sim 2$ 回の出血 & 10 回未満 \\
重 症 (severe) & 毎日 30 分以上の出血 & 10 回以上
\end{tabular}


の重症度分類としては, Rebeiz ら ${ }^{16)}$ による分類が挙げら れ, 表 2 に示すように週 $2 \sim 3$ 回程度の出血があり, 輸 血の必要のないものを軽症 (mild), 日に $1 \sim 2$ 回の出血 と 10 回未満の輸血歴を持つものを中等症 (moderate), 30 分以上の出血が毎日あり 10 回以上の輸血歴のあるも のを重症（severe）と分類している ${ }^{16)}$. 自験例ではほぼ 毎日鼻出血を認め, 出血性の貧血により輸血が必要と なっており，中等症に分類される. 欧米では，一般に軽 症から中等症の症例では, 前述の各種レーザー焼灼や各 種薬物療法, さらに塞栓術や結紮術および鼻中隔皮膚移 植術15) が選択される. 重症に分類される症例に対しては さらに前頭皮弁による鼻粘膜置換術16)17）や鼻孔閉鎖術28) が用いられている. 今回自験例はアルゴンプラズマ凝固 法により,その症状は中等症から軽症に抑えられている. この経験より APCを用いたアルゴンプラズマ凝固法は軽 症から中等症の HHT における鼻出血に対し簡便で有効 な試みる価值のある治療法といえる。しかし, APC は鼻 中隔弯曲症など鼻腔形態によって直接焼灼が不可能な部 位からの出血は抑止することが困難であり, 血管の新生 による再出血も予防できない。しかし，本手技自体は簡 便で，侵襲も軽く繰り返しての施行も可能であると考え られる．本邦では手術を必要とする重症例の報告はまれ で, 本治療の適応となる症例が多いと考えられ, 今後さ らに検討を重ねたいと考えている.

\section{まとめ}

・鼻出血にて発症した HHT 確実例を経験した.

・ 中等症と思わ机る鼻出血に対し, アルゴンプラズマ を用い有効であったのでその詳細を報告した。

\section{参考文献}

1) McAllister KA, Grogg KM, Johnson DW, et al. : Endoglin, a TGF- $\beta$ binding protein of endothelial cells, is the gene for hereditary hemorrhagic telangiectasia type 1 . Nat Genet 8 : $345 \sim 351,1994$.

2) Johnson DW, Berg JN, Gallione CJ, et al. : A second locus for hereditary hemorrhagic telangiectasia maps to chromosome 12. Genome Res $5: 21 \sim 28,1995$.

3) AAssar OS, Friedman CM and White RI Jr. : The natural history of epistaxis in hereditary hemorrhagic telangiectasia. Laryngoscope $101: 977 \sim 980,1991$.

4) Byahatti SV, Rebeiz EE and Shapshay SM : Hereditary hemorrhagic telangiectasia; what the otolaryngologist should know.
Am J Rhinol $11: 55 \sim 62,1997$.

5) Lennox PA, Harries M, Lund VJ, et al. : A retrospective study of the role of the argon laser in the management of epistaxis secondary to hereditary haemorrhagic telangiectasia. J Laryngol Otol $111: 34 \sim 37,1997$.

6) Pau H, Carney AS and Murty GE : Hereditary haemorrhagic telangiectasia (Osler-Weber-Rendu syndrome); otorhinolaryngological manifestations. Clin Otolaryngol $26: 93 \sim 98,2001$.

7) Shah RK, Dhingra JK and Shapshay SM : Hereditary hemorrhagic telangiectasia; a review of 76 cases. Laryngoscope 112 : $767 \sim 773,2002$.

8) Bergler W, Sadick H, Gotte K, et al. : Topical estrogens combined with argon plasma coagulation in the management of epistaxis in hereditary hemorrhagic telangiectasia. Ann Otol Rhinol Larygol $111: 222 \sim 228,2002$.

9) Klepfish A, Berrebi A and Schattner A : Intranasal tranexamic acid treatment for severe epistaxis in hereditary hemorrhagic telangiectasia. Arch Intern Med 161 : 767, 2001.

10) Saba HI, Morelli GA and Logrono LA : Brief report; treatment of bleeding in hereditary hemorrhagic telangiectasia with aminocaproic acid. N Engl J Med 330 : $1789 \sim$ 1790， 1994.

11) Vase $P$ and Lorentzen $M$ : Histologocal findings following oestrogen treatment of hereditary haemorrhagic telangiectasia; a controlled double-blind investigation. J Laryngol Otol $97: 427 \sim 429,1983$.

12) Lund VJ and Howard DJ : A treatment algorithm for the management of epistaxis in hereditary hemorrhagic telangiectasia. Am J Rhinol $13: 319 \sim 322$, 1999.

13) Elden L, Montanera W, Terbrugge $\mathrm{K}$, et al. : Angiographic embolization for the treatment of epistaxis; a review of 108 cases. Otolaryngol Head Neck Surg 111 : $44 \sim$ 50, 1994.

14) Harwood AR, Wojak JC and Barry R : External beam radiotherapy for severe epistaxis from Osler-Weber-Rendu disease. J La State Med Soc $154: 154 \sim$ 155, 2002.

15) Siegel MB, Keane WH, Atkins LP, et al. : Control of epistaxis in patients with hereditary hemorrhagic telangiectasia. Otolaryngol Head Neck Surg $105: 675 \sim 679,1991$.

16) Rebeiz EE, Park S and Shapshay SM : Management of epistaxis in hereditary hemorrhagic telangiectasia with Neodymium; Yttrium-Aluminum-Garnet laser photocoagulation. Oper Tech Otolaryngol Head Neck Surg 2:177 182, 1991.

17) Rebeiz EE, Bryan DJ, Ehrlichman RJ, et al. : Surgical management of life-threatening epistaxis in Osler-Weber-Rendu disease. Ann Plast Surg $35: 208 \sim 213,1995$.

18) Shovlin CL, Guttmacher AE, Buscarini E, et al. : Diagnostic criteria for hereditary hemorrhagic telangiectasia (RenduOsler-Weber syndrome). Am J Med Genet 91:66 67, 2000.

19) Porteous ME, Burn J and Proctor SJ : Hereditary haemor- 
rhagic telangiectasia; a cilinical analysis. J Med Genet $29: 527$ $\sim 530,1992$

20) Byard RW, Schliebs J and Koszyca BA : Osler-Weber-Rendu syndrome; pahtological manifestations and autopsy considerations. J Forensic Sci $46: 698 \sim 701,2001$.

21) Guttmacher AE, Marchuk DA and White RI Jr. : Hereditary hemorrhagic telangiectasia. N Engl J Med $333: 918 \sim 924$, 1995.

22) Levine HL : Endoscopy and the KTP/532 laser for nasal sinus disease. Ann Otol Rhinol Laryngol $98: 46 \sim 51,1989$.

23) Blitzer A : Laser photocoagulation in the care of patients with Osler-Weber-Rendu disease; operative technique in otolaryngology. Head Neck Surg $5: 274 \sim 277,1994$.

24) Bergler W, Riedel F, Baker-Schreyer A, et al. : Algon plasma coagulation for the treatment of hereditary hemorrhagic telangiectasia. Laryngoscope $109: 15 \sim 20,1999$.

25）深沢啓二郎, 小笠原寛, 藤井恵美, 他：アルゴンプラズマ
凝固法による下鼻甲介焼灼術. 耳鼻臨床 $92 ： 1063 \sim 1069$, 1999.

26）太田伸男：アレルギー性鼻炎に対するアルゴンプラズマ凝 固法による下鼻甲介焼灼術。山形県医師会会報誌 $598 ： 20$ $\sim 21,2001$.

27）谷浦督規，谷浦直美，谷浦倉之：APC（アルゴンプラズマ 凝固法）による治療法 VOL. 2. Tech Mag Vet Surg 5：66 $72,2001$.

28) Gluckman JL and Portugal LG : Modified Young's procedure for refractory epistaxis due to hereditary hemorrhagic telangiectasia. Laryngoscope $104: 1174 \sim 1177,1994$.

原稿受付：平成15年 4 月 24 日

原稿採択：平成15年 7 月 2 日

別刷請求先：今村俊一

₹409-3898 山梨県中巨摩郡玉穂町下河東 1110 山梨大学医学部耳鼻咽喉科教室 